AGRITECH, Vol. 37, No. 1, Februari 2017, Hal. 101-107 DOI: http://dx.doi.org/10.22146/agritech.17015 ISSN 0216-0455 (Print), ISSN 2527-3825 (Online) Tersedia online di https:/jurnal.ugm.ac.id/agritech/

\title{
Optimasi Kualitas Tandan Buah Segar Kelapa Sawit dalam Proses Panen-Angkut Menggunakan Model Dinamis
}

\author{
Optimization of Oil Palm Fresh Fruit Bunch Quality in Harvesting-Transportation Process Using A Dynamic Model
}

\section{Andreas Wahyu Krisdiarto', Lilik Sutiarso ${ }^{2}$, Kuncoro Harto Widodo ${ }^{3}$}

\author{
${ }^{1}$ Fakultas Teknologi Pertanian, Institut Pertanian Stiper, \\ Jl. Nangka II Maguwoharjo, Depok, Sleman, Yogyakarta 55282, Indonesia \\ ${ }^{2}$ Departemen Teknik Pertanian dan Biosistem, Fakultas Teknologi Pertanian, Universitas Gadjah Mada, \\ Jl. Flora No. 1, Bulaksumur, Yogyakarta 55281, Indonesia \\ ${ }^{3}$ Departemen Teknologi Industri Pertanian, Fakultas Teknologi Pertanian, Universitas Gadjah Mada, \\ Jl. Flora No. 1, Bulaksumur, Yogyakarta 55281, Indonesia \\ Email: andre0402@yahoo.com
}

Submisi: 2 Agustus 2015; Penerimaan: 26 Februari 2016

\begin{abstract}
ABSTRAK
Proses penanganan Tandan Buah Segar (TBS) kelapa sawit, yaitu pemanenan, pemuatan, dan pengangkutan ke pabrik minyak kelapa sawit merupakan kegiatan saling terkait, karena masing-masing berkontribusi terhadap penurunan kualitas. Penelitian ini bertujuan mempelajari keterkaitan antar faktor-faktor yang bersama-sama secara berurutan mempengaruhi kualitas TBS. Parameter kualitas TBS yang diamati adalah kadar Asam Lemak Bebas (ALB). Metode yang digunakan adalah mengukur kadar ALB TBS pada setiap tahap proses penanganan bahan, yaitu pemanenan, pengangkutan di dalam blok kebun, pemuatan ke bak truk, dan pengangkutan ke pabrik minyak kelapa sawit. Keterkaitan antar faktor dibangun dengan model dinamis. Keluaran dari simulasi model dinamis menunjukkan bahwa terdapat perbedaan kadar ALB antar kondisi penanganan TBS yang berbeda. Terdapat sedikit perbedaan kadar ALB antara TBS yang dipanen pada lahan mineral dan lahan gambut dan antara ketinggian pohon yang berbeda. Tahap penanganan TBS yang berkontribusi paling besar kepada penurunan kualitas akibat memar adalah pemuatan ke bak truk. TBS yang dimuat di dasar bak truk mengalami memar lebih banyak sehingga kadar ALB-nya lebih tinggi. Kadar ALB TBS yang dipanen di lahan mineral dan dimuat pada dasar bak truk 5,5\%, sedangkan yang di lapisan atas 4,5 $\%$. Model menunjukkan bahwa kadar ALB meningkat pada penanganan bahan berurutan, berbeda dengan penurunan kualitas secara alami. Proporsi buah utuh dapat digunakan untuk mengendalikan kadar ALB secara keseluruhan. Bila seluruh buah memar, kadar ALB dapat mencapai 9,95\%, sedangkan campuran $20 \%$ buah memar dan $80 \%$ buah utuh, kadar ALB-nya 2,82\%. Peningkatan proporsi buah memar dari $10 \%$ menjadi $20 \%$ untuk buah yang dipanen dari lahan mineral menyebabkan penambahan kadar ALB lebih besar daripada buah yang dipanen dari lahan gambut, yaitu 0,88 $\%$ dibanding $0,80 \%$. Hal yang sama menyebabkan perbedaan kadar ALB $0,92 \%$ untuk buah yang dipanen pada fraksi 3 dan $0,72 \%$ untuk buah dipanen pada fraksi 1 . Rekomendasi dari hasil penelitian ini adalah: 1) Pemuatan dengan pelemparan TBS secara manual sebaiknya dihindari; 2) Bila kondisi bak truk dan jalan buruk, sebaiknya TBS dipanen pada fraksi 1 atau 2;3) Titik optimum kualitas TBS saat panen dan angkut adalah pada fraksi 1 di lahan gambut dan diangkut dengan truk bak kayu, dan 4) Dari sisi kualitas TBS, penundaan pengangkutan lebih menguntungkan daripada menunggu proses (mengantri) di pabrik minyak kelapa sawit (PMKS).
\end{abstract}

Kata kunci: Model dinamis; asam lemak bebas; tandan buah segar; penanganan kelapa sawit 


\begin{abstract}
Oil palm fresh fruit bunch (FFB) handling processes, i.e harvesting, loading, and transporting to the Palm Oil Mill are interrelated activities because each of them contributed to the degradation of oil palm fruit quality. This paper presented studied among factors that together in series interfere FFB quality. FFB quality parameter observed was Free Fatty Acid (FFA) content. Experiment was conducted by measuring FFA content of FFB at each step of handling processes, i.e harvesting, transportation in plantation block, loading into truck, and transportation to the palm oil mill. Interrelationship among factors was built using dynamic modelling. Output of dynamic model simulation showed that there was differences of FFA content among different handling conditions. A slight difference on FFA content was observed between harvesting in mineral land and peatland and among different plant heights. Loading into truck was a handling step that had biggest contribution to quality degradation due to FFB bruise. FFBs laid on the base of truck bin suffered more bruise that resulted in higher FFA content. Manual loading of FFB harvested from mineral soil by throwing to the bottom of truck bin resulted in FFA content of bruised fruit by $5.5 \%$, higher compared to those of the top layer which was $4.5 \%$. Model also showed that FFA content increased due to series handling steps, compared with natural degradation. Proportion of good FFB can be used to control the whole FFA content. Without mixing, bruised FFB produced FFA content of $9.95 \%$, while mixing bruished and good fruit at a ratio $20 \%: 80 \%$ resulted in FFA content of $2.82 \%$. Increasing bruise fruit proportion from $10 \%$ to $20 \%$ resulted in higher FFA content of fruit harvested on mineral land than those harvested on peat land $(0.88 \%$ compare to $0.80 \%)$, and resulted in $0.92 \%$ increment for 3rd maturity level fruit harvested compared to $0.72 \%$ for 1 st maturity level harvested fruit. Recommendations related to harvesting were: 1) If the road and truck bin was in bad condition, FFB should be harvested at 1 st or 2 nd level of maturity; 2) The optimum harvesting-transportation condition for FFB quality was at 1st maturity level in peat land and transported by wood bin truck. While recommendations related to transportation were: 1) The manual loading by throwing to truck bin should be avoided; and 2) In order to maintain FFB quality, loading and transportation delay was better than waiting or queing in oil palm mill.
\end{abstract}

Keywords: Dynamic modelling; free fatty acid; fresh fruit bunch; oil palm handling

\section{PENDAHULUAN}

Di dalam industri minyak kelapa sawit, ketersediaan TBS kelapa sawit sebagai bahan baku minyak kelapa sawit harus dipertahankan, kuantitas dan kualitasnya. Terdapat tiga subsistem utama dalam kegiatan pascapanen, yakni pemanenan, pengangkutan dan pengolahan. Di antara ketiganya terdapat saling keterkaitan, satu hambatan di dalam satu subsistem berpengaruh terhadap kinerja subsitem yang lain. Misalnya hambatan di pengangkutan TBS dari kebun ke pabrik minyak kelapa sawit (PMKS) menyebabkan keterlambatan, yang kemudian mengganggu pengolahan minyak, kapasitas pengolahan, dan kualitas akhir minyak kelapa sawit (Pahan, 2006).

Pemanenan, pemuatan dan pengangkutan TBS sering menjadi tahap kritis dalam pengelolaan perkebunan kelapa sawit, dan kadang menjadi wilayah manajemen abu-abu antara manajemen kebun dan manajamen PMKS. Kedua divisi tersebut kadang saling menyalahkan terkait kualitas TBS, yang kemudian mempengaruhi kualitas minyak kelapa sawit. Sistem panen dan angkut yang baik diperlukan agar dapat menyediakan TBS bagi PMKS dalam jumlah maksimum dan penurunan kualitas minimum. Ketepatan metode panen akan menjamin kuantitas produksi, sedang ketepatan waktu panen akan menghasilkan TBS dengan mutu baik (Pahan, 2006). Seperti juga bahan hasil pertanian yang lain, waktu merupakan faktor yang mempengaruhi penurunan kualitas TBS. Salah satu indikator kualitas TBS adalah kadar ALB. Secara alamiah, kadar ALB setelah TBS dipanen akan meningkat $0,1 \%$ setiap 24 jam (Lubis, 1992), di sisi lain kadar ini tidak boleh lebih dari 2-3\% pada saat masuk proses di PMKS (Mangoensoekarjo dan Tojib, 2008). Penurunan kualitas ini akan lebih cepat yang disebabkan oleh penanganan secara fisik. Sementara itu proses panen dan angkut tidak bisa sepenuhnya dihindarkan dari perlakuan fisik. Kerusakan buah pada tahap panen-angkut akan menjadi pemicu penurunan kualitas di tahap berikutnya, karena memar atau luka yang diderita buah akan mempercepat kenaikan kadar ALB. Kadar ALB akan meningkat cepat jika struktur sel rusak/pecah, misalnya oleh karena impak fisik (Yuwana dkk., 2009). Hal ini dikarenakan oleh pecahnya dinding sel dan aktivitas enzim lipase. Pemanenan dan pengangkutan harus dilakukan dalam kerangka mencapai produktivitas minyak tertinggi dengan kualitas yang dapat diterima konsumen dan dengan biaya serendah-rendahnya. Oleh sebab itu keterkaitan antar faktor perlu dipertimbangkan.

Jaringan antar faktor dalam panen-angkut TBS yang saling terkait dan pengaruhnya terhadap kualitas akhir dari waktu ke waktu merupakan sebuah sistem dinamis. Kerangka sistem dinamis dapat dipergunakan untuk memahami 
fenomena peningkatan kadar ALB secara berurutan, sehingga dapat dipelajari titik kritis penurunan kualitas TBS. Dalam upaya menentukan kebijakan agar dapat menahan penurunan kualitas selama panen-angkut, dapat dibangun model dinamis yang dapat merepresentasikan perilaku sistem panen angkut bila ada perubahan kebijakan.

Penelitian ini bertujuan membangun model dinamis yang diharapkan dapat menjadi salah satu acuan dalam menentukan waktu dan metode penanganan TBS, baik pada pemanenan, pemuatan ke truk, dan pengangkutan.

\section{METODE PENELITIAN}

Obyek penelitian ini adalah sistem pemanenan, pemuatan dan pengangkutan TBS di kebun inti perkebunan kelapa sawit perusahaan swasta di Provinsi Sulawesi Barat. Kondisi pertanaman kelapa sawit adalah sudah menghasilkan (Tanaman Menghasilkan, TM). Kualitas TBS diamati berdasarkan pada kerusakan atau memar buah kelapa sawit. Cuplikan diambil secara acak dari beberapa afdeling yang memenuhi kriteria perlakuan. Perlakuan selama penelitian adalah tingkat kematangan TBS, jenis lahan, ketinggian pohon, jarak angkut dalam blok, posisi di dalam bak truk, dan kondisi jalan. Subsistem panen-angkut yang tercakup dalam pengamatan penelitian ini adalah pemanenan, pengangkutan TBS dari pohon ke Tempat Pengumpulan Hasil (TPH), pemuatan buah ke bak truk, dan pengangkutan TBS dari TPH ke loading ramp sebagai stasiun penerimaan di PMKS (Gambar 1).

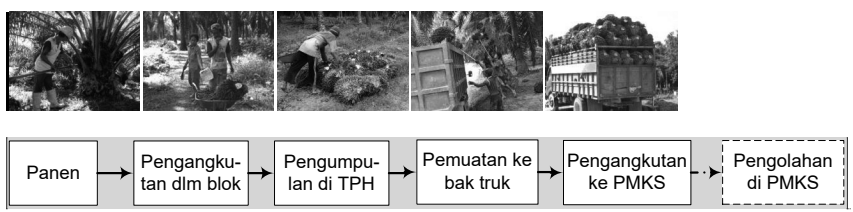

Gambar 1. Subsistem pascapanen kelapa sawit yang tercakup dalam penelitian

Cuplikan buah diwakili dengan 750 gram buah brondol yang diambil dari setiap perlakuan. Parameter utama penelitian adalah kadar ALB (\%). Kadar ALB dapat diperkirakan dengan luasan memar dan proporsi berat buah yang memar tersebut, yaitu dengan menetapkan indeks memar TBS (Hadi dkk., 2009). Tingkat memar diklasifikasikan menjadi 4 menurut luasan memar dan pengaruhnya terhadap kadar ALB. Di akhir tahapan penelitian, kadar ALB diukur di laboratorium mengikuti metode yang disusun Sudarmadji dkk. (1997).

Penelitian dibagi dalam dua tahap. Tahap pertama mengumpulkan data buah rusak dan analisa kadar ALB nya. Tahap kedua mengembangkan model dinamis. Percobaan dilakukan di lapangan, mengikuti sistem pemanenan dan pengangkutan yang dilaksanakan oleh perusahaan kelapa sawit. Perlakuan pemanenan adalah tingkat kematangan (fraksi), jenis lahan, dan ketinggian pohon. Aras perlakuan kematangan adalah fraksi 1 (belum matang), fraksi 2 (mulai matang), dan fraksi 3 (matang). Aras jenis lahan adalah lahan mineral dan lahan gambut. Aras ketinggian pohon adalah 3 $\mathrm{m}, 6 \mathrm{~m}$, dan $10 \mathrm{~m}$. Perlakuan angkutan di dalam blok tanaman adalah jarak pengangkutan. Sedang aras pengangkutan ke PMKS meliputi jenis bak truk (kayu dan besi) dan posisi TBS di bak truk (lapisan dasar dan lapisan atas). Dalam penelitian ini diasumsikan varietas pohon kelapa sawit adalah sama.

Identifikasi kerusakan buah menggunakan indeks memar yang ditetapkan oleh Hadi dkk. (2009) dalam persamaan 1.

$$
\text { Indeks Memar }=\frac{X_{1}+2,5 X_{2}+5,5 X_{3}+10 X_{4}}{100}
$$

Dimana $\mathrm{X}_{1}, \mathrm{X}_{2}, \mathrm{X}_{3}$ and $\mathrm{X}_{4}$ adalah prosentase berat buah tanpa memar (A), memar ringan(B), memar sedang (C) dan memar berat (D).

A: buah baik, tanpa memar atau luka kulit, disamakan dengan Indeks Memar 1,0

B: buah memar ringan, total luas memar kurang dari 1 $\mathrm{cm}^{2}$, disamakan dengan Indeks Memar $=2,5$

C: buah memar sedang, total area memar antara 1-2 $\mathrm{cm}^{2}$, disamakan dengan Indeks Memar $=5,5$

D: buah memar berat, total area memar lebih dari 2 $\mathrm{cm}^{2}$, disamakan dengan Indeks Memar $=10$

Indeks memar kemudian digunakan sebagai dasar untuk menghitung kadar ALB, menggunakan persamaaan 2 dan 3 (Hadi dkk., 2009)

FFA (mulai matang) $=0,122+0,502 \times \mathrm{IM}$
FFA $($ matang $)=0,76+1,287 \times \mathrm{IM}$

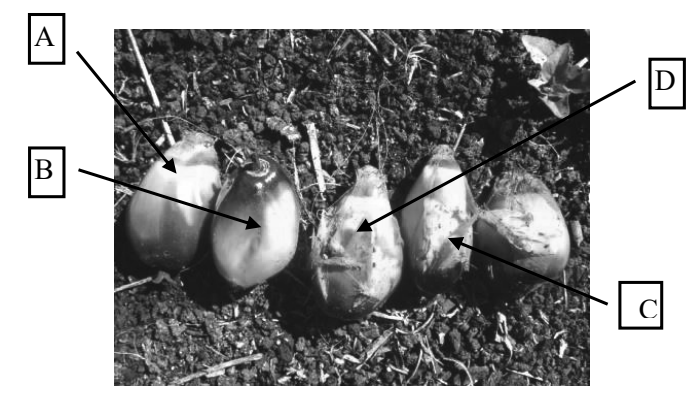

Gambar 2. Buah dari TBS yang dipanen : A. Utuh (tanpa memar), B. Memar atau luka ringan, C. Memar sedang, D. Memar berat.

Data hasil analisa digunakan untuk mengembangkan model dinamis berdasar diagram sebab akibat yang dibangun, seperti tersaji pada Gambar 3. Pendekatan sistem dinamis dipergunakan mengingat adanya keterkaitan kualitas TBS 
dengan waktu setelah panen. Terjadinya pelukaan pada buah dalam proses panen angkut menyebabkan peningkatan kadar ALB berlipat ganda dalam waktu yang sama (Corley, 2003) atau penundaan waktu menyebabkan kadar ALB meningkat (Budiyanto dkk., 2005). Pengembangan model dinamis dan simulasi menggunakan software Powersim.

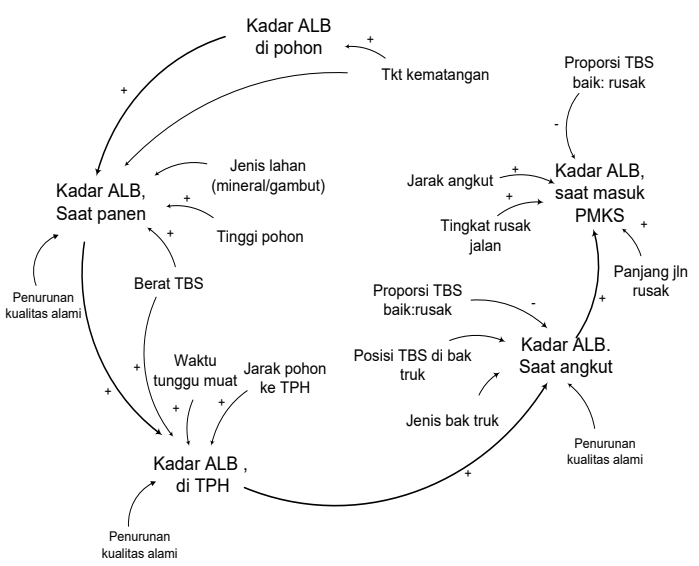

Gambar 3. Diagram sebab akibat sistem pemanenan, pemuatan, dan pengangkutan TBS dalam kaitan dengan kadar ALB sebagai indikator kualitas TBS.

Kemudian model disimulasikan dengan beberapa skenario untuk mendekati kondisi lapangan. Skenario untuk kegiatan pemanenan adalah tingkat kematangan dan jenis lahan. Skenario untuk pemuatan dan pengangkutan adalah bak kayu dan bak besi (dump truck) dan posisi TBS di dalam bak. Simulasi juga dilakukan dengan skenario proporsi buah memar, yaitu tanpa buah memar (atau $100 \%$ utuh), $10 \%$ buah memar (sama dengan $90 \%$ buah utuh), dan $20 \%$ buah memar (sama dengan $80 \%$ buah utuh). Proporsi ini mengikuti ratarata proporsi buah di lapangan. Model disimulasikan untuk 60 menit proses, dari saat panen sampai dengan masuk loading ramp. Diasumsikan bahwa setelah dipanen TBS diangkut ke TPH pada menit ke 21 selama 5 menit. Kemudian menunggu di TPH selama 15 menit, dan dimuat ke truk pengangkut pada menit ke 41, dengan waktu muat 5 menit. Setelah itu diangkut ke PMKS menggunakan truk. Penetapan waktu untuk simulasi tersebut berdasarkan pada kondisi lapangan pengangkutan bagi blok-blok lahan yang dalam jangkauan 10-15 km dari PMKS. Untuk mengetahui kadar ALB TBS akhir sebenarnya, dilakukan pengukuran laboratorium ALB saat TBS di loading ramp, sebelum TBS mulai diproses di PMKS.

\section{HASIL DAN PEMBAHASAN}

Dalam penelitian ini peningkatan kadar ALB oleh karena memar atau rusak buah diamati pada tiap tahap dalam proses panen-angkut TBS. Faktor-faktor berpengaruh dalam sistem yang dicakup dalam diagram sebab akibat tersaji dalam Gambar 3. Kadar ALB TBS setelah dipanen tanpa kerusakan secara alamiah mengalami kenaikan yang digambarkan dalam kurva asimptot oleh Turner dan Gillbanks (2003), sedangkan pada buah yang memar atau luka mengalami kenaikan lebih tajam, mengacu kepada hasil penelitian Corley (2003).

Hasil analisis menunjukkan bahwa terdapat perbedaan kadar ALB awal pada kondisi pemanenan yang berbeda. Sebagai contoh pemanenan pada tingkat kematangan (fraksi) 1, 2 dan 3 masing-masing adalah 1,7\%, 1,8\%, dan 2,1\%. Hasil penelitian Krisdiarto dan Sutiarso (2016a) memperlihatkan bahwa tidak terdapat perbedaan kadar ALB karena jarak pengangkutan yang berbeda di dalam blok kebun. Namun tampak perbedaan peningkatan antara TBS yang terletak di dasar dan di lapisan atas bak truk, demikian juga antara yang diangkut menggunakan bak berbahan kayu dan berbahan bak besi. Kadar ALB buah memar yang dipanen pada lahan mineral, dimuat dengan pelemparan ke lapisan dasar bak truk mencapai 5,5\%, sedang yang di lapisan bawah 4,5\%. Hal ini karena pemuatan TBS dengan cara dilempar mengakibatkan luka atau memar, terutama untuk lapisan terbawah di bak truk (Krisdiarto dan Sutiarso, 2016b). Potensi memar lebih besar jika TBS dipanen pada fraksi lebih tinggi, karena secara alamiah, semakin matang buah, kandungan ALB semakin tinggi, dan secara fisik kulit luar lebih lunak. Uji jatuh TBS yang dilakukan Krisdiarto dan Sutiarso (2016a) juga memperlihatkan bahwa jumlah buah lepas (brondolan) yang memar pada fraksi 1,2 dan 3 masing-masing 15,6, 16,3, dan 20,1 , yang menegaskan semakin tinggi fraksi panen, buah semakin lemah.

\section{Pengaruh Tingkat Kematangan Berbeda}

Tingkat kematangan saat panen menjadi faktor kritis dalam pengelolaan panen, karena terkait dengan rendemen dan kadar ALB. Pada perkebunan kelapa sawit di Indonesia, umumnya TBS dipanen pada fraksi 2-3. Grafik dalam Gambar 4 menyajikan hasil simulasi kadar ALB panen pada tingkat kematangan berbeda. Kurva 8 menyajikan kadar ALB buah sawit tanpa memar atau penurunan kualitas secara alamiah, sedangkan kurva 1 menyajikan kadar ALB TBS yang dipanen pada fraksi 1 dan memar dalam rentang waktu proses angkutan 60 menit, yang dapat mencapai 9,83\%. Kurva 2-7 menyajikan kadar ALB TBS luaran simulasi campuran $10 \%$ buah memar dan $90 \%$ buah utuh. Bila proporsi campuran sama, kadar ALB buah yang dipanen pada fraksi 3 akan lebih tinggi daripada yang dipanen pada fraksi 2. Tabel 1 memperlihatkan hasil simulasi dengan skenario proporsi buah memar terhadap buah utuh, jenis bak truk, dan posisi TBS dalam bak truk. Tampak bahwa terdapat perbedaan kadar ALB dari TBS yang diangkut dengan sarana jenis bak truk berbeda dan pada posisi di lapisan bak truk yang berbeda. Hal ini karena TBS 


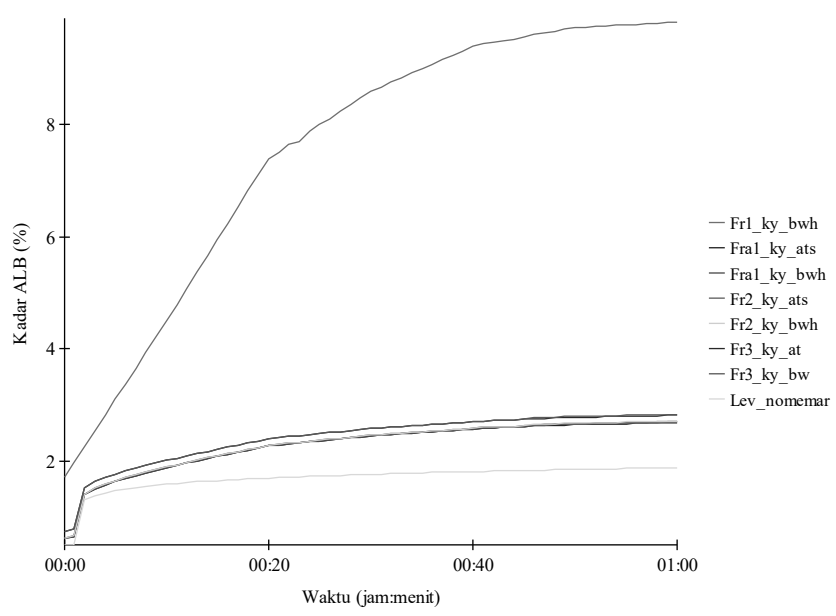

Ket legenda grafik:

Kode Fr1 ky bwh; fraksi 1; jenis bak truk kayu; posisi TBS di bak truk dasar Kode Fra1 ky ats; fraksi 1; jenis bak truk kayu; posisi TBS di bak truk atas Kode Fra1 ky bwh; fraksi 1; jenis bak truk kayu; posisi TBS di bak truk dasar Kode Fr2 ky ats; fraksi 2; jenis bak truk kayu; posisi TBS di bak truk atas Kode Fr2 ky bwh; fraksi 2; jenis bak truk kayu; posisi TBS di bak truk dasar Kode Fr3 ky at; fraksi 3; jenis bak truk kayu; posisi TBS di bak truk atas Kode Fr3 ky bw; fraksi 3; jenis bak truk kayu; posisi TBS di bak truk dasar Kode Lev nomemar; tanpa memar

Gambar 4. Luaran simulasi dengan skenario tingkat kematangan (fraksi) saat panen

Tabel 1. Kadar ALB hasil simulasi 60 menit model dengan skenario fraksi panen, jenis truk, posisi TBS dalam bak truk dan proporsi TBS utuh dan memar

\begin{tabular}{lcccc}
\hline $\begin{array}{c}\text { Tingkat } \\
\text { kematangan } \\
\text { (fraksi panen) }\end{array}$ & $\begin{array}{c}\text { Jenis bak } \\
\text { truk }\end{array}$ & Posisi TBS dalam bak truk & $\begin{array}{c}\text { ALB (\%) } \\
10: 90\end{array}$ & $\begin{array}{c}\text { ALB (\%) } \\
20: 80\end{array}$ \\
\hline $1^{*}$ & kayu & atas & 9,83 & 9,83 \\
\hline 1 & kayu & atas & 2,69 & 3,48 \\
& & dasar & 2,70 & 3,49 \\
& besi & atas & 2,71 & 3,50 \\
& kayu & dasar & 2,72 & 3,51 \\
\hline 2 & atas & 2,70 & 3,50 \\
& besi & dasar & 2,71 & 3,52 \\
& & atas & 2,72 & 3,52 \\
& kayu & dasar & 2,73 & 3,54 \\
\hline 3 & & atas & 2,82 & 3,74 \\
& besi & dasar & 2,83 & 3,75 \\
& & atas & 2,84 & 3,76 \\
& dasar & 2,85 & 3,77 \\
\hline
\end{tabular}

* Diasumsikan keseluruhan buah memar

di lapisan bawah menderita tekanan dan beban oleh TBS di atasnya, demikian juga di lapisan bawah akan lebih banyak gesekan dan memar. Kadar ALB juga semakin tinggi bila buah tidak terangkut (restan), yang mungkin disebabkan oleh kondisi jalan yang buruk (Krisdiarto dan Santosa, 2012). Bila proporsi TBS memar atau luka naik menjadi $20 \%$, akan terjadi peningkatan kadar ALB secara keseluruhan kurang lebih $0,8 \%$. Peningkatan kadar ALB ini akan terjadi lebih tinggi untuk buah dengan fraksi panen 3 dibanding fraksi $1(0,92 \%$ dibanding $0,72 \%$ ). Hal ini menunjukkan peningkatan jumlah buah memar berpengaruh terhadap kadar ALB yang cukup nyata, terutama bila buah dipanen pada fraksi 3 , karena buah yang lebih matang memiliki kadar ALB lebih tinggi. Kadar ALB di akhir proses simulasi, yakni saat di loading ramp, adalah 2,69-3,77\%, sementara hasil pengukuran laboratorium sebesar 2,52-2,76\%.

\section{Pengaruh Jenis Lahan Berbeda}

Grafik dalam Gambar 5 merupakan hasil simulasi ketika pemanenan dilakanakan di lahan mineral dan lahan gambut, pada beberapa ketinggian pohon. Kurva 11 menyajikan kadar ALB buah yang utuh (tidak memar) selama. Kurva 1 sampai 6 memperlihatkan bahwa terdapat perbedaan kadar ALB TBS yang dipanen dari pohon ketinggian 3, 6 dan 10 m. Menggunakan skenario campuran $10 \%$ buah memar dan

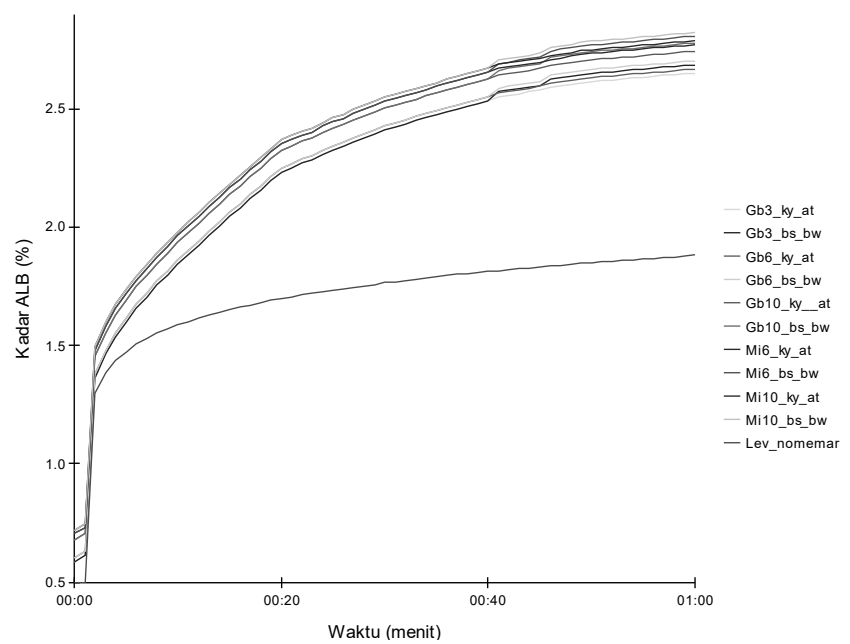

Ket legenda grafik:

Kode $\mathrm{Gb} 3 \mathrm{ky}$ at; jenis lahan gambut; tinggi pohon dipanen $3 \mathrm{~m}$; jenis bak truk kayu; posisi TBS di bak truk atas

Kode Gb3 bs bw; jenis lahan gambut; tinggi pohon dipanen $3 \mathrm{~m}$; jenis bak truk besi; posisi TBS di bak truk dasar

Kode Gb6 ky at; jenis lahan gambut; tinggi pohon dipanen $6 \mathrm{~m}$; jenis bak truk kayu; posisi TBS di bak truk atas

Kode Gb6 bs bw; jenis lahan gambut; tinggi pohon dipanen 6 m; jenis bak truk besi; posisi TBS di bak truk dasar

Kode Gb10 ky at; jenis lahan gambut; tinggi pohon dipanen 10 m; jenis bak truk kayu; posisi TBS di bak truk atas

Kode Gb10 bs bw; jenis lahan gambut; tinggi pohon dipanen 10 m; jenis bak truk besi; posisi TBS di bak truk dasar

Kode Mi6 ky at; jenis lahan mineral; tinggi pohon dipanen $6 \mathrm{~m}$; jenis bak truk kayu; posisi TBS di bak truk atas

Kode Mi6 bs bw; jenis lahan mineral; tinggi pohon dipanen 6 m; jenis bak truk besi; posisi TBS di bak truk dasar

Kode Mi10 ky at; jenis lahan mineral; tinggi pohon dipanen 10 m; jenis bak truk kayu; posisi TBS di bak truk atas

Kode Mi10 bs bw; jenis lahan mineral; tinggi pohon dipanen 10 m; jenis bak truk besi; posisi TBS di bak truk bawah

Kode Lev nomemar; tanpa memar

Gambar 5. Luaran simulasi dengan skenario jenis lahan dan ketinggian pohon 
Tabel 2. Kadar ALB hasil simulasi model 60 menit skenario jenis lahan, ketinggian pohon dan proporsi TBS utuh dan memar

\begin{tabular}{ccllcc}
\hline Jenis lahan & Tinggi pohon dipanen $(\mathrm{m})$ & Jenis bak truk & Posisi TBS di bak truk & ALB (\%) $10: 90$ & ALB (\%) $20: 80$ \\
\hline Gambut & 3 & kayu & atas & 2,65 & 3,41 \\
Gambut & 3 & besi & dasar & 2,69 & 3,44 \\
Gambut & 6 & kayu & atas & 2,67 & 3,44 \\
Gambut & 6 & besi & dasar & 2,70 & 3,48 \\
Gambut & 10 & kayu & atas & 2,74 & 3,59 \\
Gambut & 10 & besi & dasar & 2,76 & 3,63 \\
\hline Mineral & 3 & kayu & atas & $9,87 *$ & 3,49 \\
Mineral & 3 & besi & dasar & $9,90 *$ & 3,52 \\
Mineral & 6 & kayu & atas & 2,77 & 3,65 \\
Mineral & 6 & besi & dasar & 2,81 & 3,68 \\
Mineral & 10 & kayu & atas & 2,79 & 3,68 \\
Mineral & 10 & besi & dasar & 2,82 & 3,71 \\
\hline
\end{tabular}

*Diasumsikan keseluruhan buah memar

$90 \%$ buah utuh yang diproses, tampak perbedaan antara kurva 1-6 dan 7-10. Ini menunjukkan adanya perbedaan bahwa pemanenan di lahan gambut bisa memberikan kadar ALB lebih rendah. Hal ini terkait dengan karakteristik tanah mineral yang lebih keras daripada tanah gambut. Pada umumnya tanah gambut memiliki daya dukung lebih rendah atau memiliki sifat pegas, sehingga gaya yang disebabkan buah jatuh dapat ditahan dan impak nya lebih kecil. Tanah gambut dapat bersifat seperti bantal untuk TBS yang jatuh. Daya dukung per $\mathrm{cm}^{2}$ tanah di lokasi hasil pengamatan adalah 4,6-9,6 kg untuk lahan mineral dan 2,6-6,1 kg untuk lahan gambut (Krisdiarto dan Sutiarso, 2016a). Seperti juga simulasi dengan skenario fraksi saat panen, pada simulasi dengan skenario perbedaan jenis lahan peningkatan proporsi TBS memar menyebabkan peningkatan kadar ALB. Peningkatan proporsi buah memar dari $10 \%$ menjadi $20 \%$ pada lahan gambut menyebabkan kadar ALB naik rata-rata $0,80 \%$, sedangkan pada lahan mineral $0,88 \%$. Ini menunjukkan bahwa pengendalian proporsi buah memar di lahan mineral lebih kritis daripada di lahan gambut.

Keterkaitan antar faktor dalam manajemen kelapa sawit dapat dipelajari dengan model dinamis (Wiguna dkk., 2009; Widodo dkk., 2010). Model dinamis juga dapat membantu pengambilan kebijakan dalam pengelolaan panen-angkut TBS kelapa sawit. Model yang dibangun dapat mewakili peningkatan kadar ALB, baik secara alamiah maupun karena perlakuan fisik selama proses pasca panen. Tahap kritis peningkatan ALB dapat diamati lebih rinci (Krisdiarto dan Sutiarso, 2016a). Bila akan diterapkan perlakuan teknologi dalam proses ini, misalnya sistem jaring, pengaruhnya terhadap kadar ALB di akhir proses dapat dipelajari dengan model ini.
Nilai yang berbeda-beda hasil simulasi yang tersaji pada Tabel 1 dan Tabel 2 memperlihatkan faktor-faktor perlakuan saling terkait mempengaruhi kadar akhir ALB buah kelapa sawit dalam proses panen angkut. Misalnya TBS yang dipanen pada lahan gambut dengan ketinggian pohon 3 m diangkut dengan truk bak kayu kadar ALB saat di loading ramp akan berbeda, tergantung kepada posisinya di bak truk. Demikian juga faktor tingkat kematangan TBS saat dipanen akan berpengaruh bersama-sama dengan jenis bak truk dan posisinya di dalam bak truk. Pengaruh penambahan kadar ALB ini terjadi sesuai dengan waktu dimana proses tersebut terjadi, misalnya penambahan ALB saat pemuatan ke atas bak truk dan selama pengangkutan. Grafik pada Gambar 4 dan 5 juga memperlihatkan faktor waktu perlu diperhatikan dalam proses panen angkut. Dalam grafik tersebut kenaikan kadar ALB cukup tajam pada saat menit ke-5, kemudian terjadi lagi peningkatan kadar ALB di menit ke 21 dan 40, sesuai dengan tahap proses penanganan bahan. Kenaikan tersebut kemudian diikuti dengan peningkatan kadar ALB. Ini berarti bila tahap penanganan bahan yang berpotensi melukai ditunda, kadar ALB akhir di loading ramp akan lebih rendah. Dalam praktek di lapangan, bila terjadi jumlah TBS yang datang jauh lebih banyak daripada kapasitas PMKS mengolah, kualitas TBS lebih dapat dijaga dengan menunda pemuatan dan pengangkutan (TBS dibiarkan utuh di kebun) daripada TBS diangkut lebih awal namun harus menunggu proses (mengantri) di PMKS.

\section{KESIMPULAN}

Memar atau luka buah kelapa sawit pada satu tahap panen angkut akan berpengaruh terhadap kualitas TBS pada tahap 
berikutnya dalam sistem pasca panen. Tingkat kematangan buah saat pemanenan yang berbeda, menyebabkan awal kadar ALB berbeda, yaitu 1,7\%, 1,8\%, dan 2,1\%. Jenis lahan dan ketinggian pohon menyebabkan titik awal kadar ALB berbeda. Demikian juga kondisi saat pengangkutan seperti jenis bak truk dan posisi TBS di dalam lapisan bak truk memberikan tambahan kadar ALB yang berbeda. Selisih kadar ALB TBS memar antara di lapisan atas dan bawah bak truk sebesar 1 $\%$. Bila keseluruhan yang diproses adalah buah memar, kadar ALB mencapai 9,95\%. Peningkatan proporsi buah memar dari $10 \%$ menjadi $20 \%$ pada lahan mineral menyebabkan penambahan kadar ALB lebih besar daripada di lahan gambut, yaitu $0,88 \%$ dibanding $0,80 \%$. Hal yang sama menyebabkan perbedaan kadar ALB buah antara yang dipanen pada fraksi 3 dan pada fraksi $1 \mathrm{~m}$, yaitu $0,92 \%$ dibanding $0,72 \%$. Model yang dibangun dapat merepresentasikan peningkatan kadar ALB dalam proses panen angkut secara dinamis. Model merekomendasikan titik optimum kualitas TBS saat panen dan angkut adalah pada fraksi 1 di lahan gambut dan diangkut dengan truk bak kayu. Dari sisi kualitas TBS, penundaan pengangkutan lebih menguntungkan daripada menunggu proses (mengantri) di PMKS.

\section{UCAPAN TERIMA KASIH}

Terima kasih disampaikan kepada PT Letawa, Astra Agro Lestari, Sulawesi Barat, atas semua fasilitas dan bantuan selama penelitian lapangan, serta kepada Ditjen Pendidikan Tinggi, Kementerian Pendidikan Nasional, atas bantuan pendanaan dari skema Hibah Bersaing (kontrak no 023/04.2.189971/2013 tanggal 1 Mei 2013).

\section{DAFTAR PUSTAKA}

Budiyanto, Mudjiharjo, S. dan Sabri, C.S. (2005). Identifikasi kerusakan buah sawit dan pengaruh penundaan pengolahan terhadap peningkatan kandungan ALB pada buah sawit. Jurnal Ilmu-Ilmu Pertanian Indonesia 7(2): 133-139.

Corley, R.H.V. dan Tinker, P.B. (2003). The Oil Palm. Ed. 4. Blackwell Science Inc., Iowa, USA.

Hadi, S.,D., Ahmad, F.B, dan Akande. (2009). Determination of the bruise indexes of oil palm fruits. Journal of Food Engineering 95: 322-326.

Krisdiarto, A.W. dan Santosa, T.N.B. (2012). Keterkaitan infrastruktur jalan dan hujan terhadap tingkat restan TBS pada perkebunan kelapa sawit. Prosiding Seminar Nasional Keteknikan Pertanian: "Peran keteknikan pertanian dalam pembangunan industri pertanian berkelanjutan berbasis kearifan lokal'. Universitas
Udayana, Denpasar. Hal. 211-220.

Krisdiarto, A.W. dan Sutiarso, L. (2016a). Study on oil palm fresh fruit bunch bruise in harvesting and transportation as a function to quality. Makara Journal of Technology 20: $67-72$

Krisdiarto, A.W. dan Sutiarso, L. (2016b). Pengaruh kerusakan jalan perkebunan dan posisi TBS di bak truk terhadap kinerja pengangkutan kelapa sawit. Agritech 36(2): 219-225.

Krisdiarto, A.W., Sutiarso, L., dan Widodo, K.H. (2015). Study on oil palm fresh fruit bunch quality in palm oil postharvest process using dynamic modelling. The 7th International conference on sustainable agriculture for food, energy and industry in regional and global context (ICSAFEI 2015.) 25-27 August 2015. UPM, Kuala Lumpur, Malaysia.

Lubis, A.U. (1992). Oil Palm in Indonesia. Plantation Research Centre, Pematang Siantar.

Pahan, I. (2006). Panduan Lengkap Kelapa Sawit, Manajemen Agribisnis dari Hulu Hingga Hilir. Penebar Swadaya, Jakarta.

Mangoensoekarjo, S. dan Tojib, A.T. (2008). Manajemen budidaya kelapa sawit. Dalam: Mangoensoekarjo, S. dan Semangun, H. (ed). Manajemen Agribisnis Kelapa Sawit, hal 275-279. Gadjah Mada University Press, Yogyakarta.

Sudarmadji, S., Bambang, H., dan Suhardi (1997). Prosedur Analisa untuk Bahan Makanan dan Pertanian. Liberty, Yogyakarta.

Turner, P.D. dan Gillbanks, R.A. (2003). Oil Palm Cultivation and Management. The Incorporated of Planters Society, Malaysia.

Widodo, K.H., Abdullah, A., Kharies P.D.A. (2010). Sistem supply chain crude-palm-oil Indonesia dengan mempertimbangkan aspek economical revenue, social welfare dan environment. Jurnal Teknik Industri 12(1): 47-54.

Wiguna, I.G.P. dan Hermanto, S. (2009). Design of sustainable oil palm smallholding plantation management using dynamic system approach. Agro Ekonomi 27(1): 81108 .

Yuwana, H., Lukman, dan Sidebang, B. (2009). Kajian benturan buah kelapa sawit (elais guinesis) pada berbagai permukaan sebagai upaya mengurangi kerusakan buah penyebab penurunan kualitas bahan baku pangan. Laporan Penelitian HIBAH Penelitian Strategis Nasional. Fakultas Pertanian, Universitas Bengkulu. Bengkulu. 